\title{
Pengaruh minat dan motivasi belajar terhadap prestasi belajar mahasiswa program studi manajemen divisi kamar angkatan 2018/2019 di politeknik pariwisata batam \\ Devid Trinaldo Simatupang
}

Manajemen Divisi Kamar,Politeknik Pariwisata Batam, Jl. Gajah Mada, The Vitka City Complex, Tiban Ayu, Sekupang, Batam, Indonesia

\begin{abstract}
Abstrak
Prestasi belajar mahasiswa dipengaruhi oleh faktor internal d a n eksternal. Min at d an motivasi a dalah faktor internalyang mempengaruhi prestasi belajar. Seseorang dengan minat y ang ren dah ketika mengawali suatu kegiatan akan memiliki rasa malas dan tidak tertarik untuk melanjutkan dan tanpa diim ba ngi motivasi bela jar y ang tinggi menyebabkan perhatian terhadap pelajaran akan terganggu. Populasi penelitian ini a dalah mahasiswa Angkatan 2018/2019 sebanyak 108 siswa dan sampel ya ng diambil a dalah 85 mahasiswa. Berdasarkan hasil penelitian dapat diambil kesimpulan bahwa a da pengaruh min at belajar dan motivasi belajar terhadap prestasi belajar mahasiswa Angkatan 2018/2019 Politeknik Pariwisa ta Batam secara parsial maupun simultan. Hasil penelitian tersebut menyarankan kepada mahasiswa agar menin gkatkan minat dan motivasi belajarnya serta peran serta pendidik dan orang tua sangat diperlukan.
\end{abstract}

Kata Kunci : Minat belajar, motivasi, prestasi mahasiswa, pembelajaran

\section{Abstract}

Student learning a chievement is affected by internal and external factors. Interest and motiv ation are internal factors that affect student lea rning a chievement. In learning process, some student become la zy and low enthusiasm because there is no motivation and it affect to their focus in class. The population of this study was the room division management students of the 2018/2019 class and there are 108 students and the sample taken was 85 students. The results of the study indicate that there is an influence of interest learning and motivation on student a chievement. The results of this study suggest to students to inc rease their interest lea rning and motivation and the participation of educators and parents is needed.

Key words: Interest lea rning, motivation, student achievement, student learning

\section{PENDAHULUAN}

Pendidikan adalah usaha sadar untuk menumbuhkembangkan sumber daya manusia (SDM) melalui kegiatan pengajaran. Berlangsungnya proses pembelajaran, maka bersama itu pula terjadi proses belajar. Belajar di sini menurut Sardiman (2010:21) diartikan sebagai usaha mengubah tingkah laku. Terdapat beberapa teori yang berpendapat bahwa proses belajar bertumpu pada struktur kognitif, yakni penataan fakta, konsep serta prisip-prinsip, sehingga membentuk satu kesatuan yang memiliki makna bagi subjek didik. Proses belajar- mengajar ini kemudian akan memperoleh suatu hasil, yang pada umumnya disebut hasil pembelajaran, atau dengan istilah tujuan pembelajaran.

Politeknik Pariwisata Batam berusaha meningkatkan mutu pendidikan melalui visinya (https://btp.ac.id/) yaitu Menjadi Institusi Pendidikan Tinggi Kepariwisataan Terkemuka di Asia Tenggara, dengan memiliki misi sebagai berikut:

a. Meningkatkan kualitas pendidikan dan pengajaran bidang pariwisata melalui pengembangan kapasitas belajar;

b. Meningkatkan kualitas dan ragam penelitian untuk pengembangan keilmuan dan teknologi kepariwisataan berbasis kearifan lokal;

c. Meningkatkan kapasitas aplikasi keilmuan pariwisata melalui pengabdian masyarakat dalam rangka meningkatkan kesejahteraan masyarakat;

d. Memposisikan diri sebagai agen pembaharu dalam mendorong kemandirian pembangunan kepariwisataan nasional; 
e. Berperan sebagai simpul utama jejaring pendidikan tinggi kepariwisataan Indonesia.

Sedangkan tujuannya antara lain:

a. Menghasilkan kualitas pendidikan dan pengajaran bidang pariwisata melalui pengembangan kapasistas belajar guna menghasilkan lulusan yang professional;

b. Menghasilkan ragam penelitian untuk pengembangan keilmuan dan teknologi kepariwisataan berbasis kearifan lokal;

c. Menyebarluaskan aplikasi keilmuan pariwisata melalui pengabdian masyarakat dalam rangka meningkatkan kesejahteraan masyarakat;

d. Sebagai agen pembaharu dalam mendorong kemandirian pembangunan kepariwisataan nasional;

e. Menjadi simpul utama dalam jejaring pendidikan tinggi kepariwisataan Indonesia.

Sasaran yang dimiliki ialah sebagai berikut:

Untuk mencapai tujuan yang dirumuskan diatas, ditetapkan sasaran pengembangan Politeknik Pariwisata Batam lima (5) tahun ke depan sebagai berikut:

a. Meningkatkan kontribusi dalam memenuhi kebutuhan sumber daya manusia berkualitas untuk pengembangan dunia pariwisata;

b. Meningkatkan mutu layanan akademik, pembelajaran, pembimbingan yang bermuara pada peningkatan hasil pembelajaran dan karya tulis ilmiah mahasiswa;

c. Meningkatkan karya penelitian terapan dalam rangka pengembangan ilmu pengetahuan

d. Meningkatkan jumlah penelitian serta pengabdian kepada masyarakat yang berkualitas sesuai dengan kebutuhan stakeholder;

e. Meningkatkan aktivitas dan kualitas penelitian sesuai dengan arah kebijakan penelitian Politeknik Pariwisata Batam yang bermuara pada meningkatnya jumlah publikasi nasional dan internasional, serta pemerolehan HKI;

f. Meningkatkan aktivitas dan kualitas pengabdian kepada masyarakat secara melembaga yang berbasis inovasi dan hasil-hasil penelitian;

g. Meningkatkan Kerjasama untuk mensinergikan potensi sumber daya yang dimiliki.

Prestasi belajar pariwisata adalah hasil yang dicapai oleh peserta didik dalam kegiatan belajar pariwisata yang ditunjukkan dengan nilai atau angka dari hasil evaluasi setelah proses pembelajaran. Berdasarkan data yang ada menunjukkan bahwa prestasi belajar mahasiswa angkatan tahun 2018/2019 rata-rata prestasinya sebesar 79,35. Adapun data dapat dilihat dalam tabel 1.2 di bawah ini:

\section{Tabel 1.1 Prestasi Belajar Mahasiswa Politeknik Pariwisata Batam Angkatan 2018/2019}

\begin{tabular}{|c|l|c|}
\hline No. & $\begin{array}{l}\text { Mata Kuliah Manajemen } \\
\text { Divisi Kamar }\end{array}$ & $\begin{array}{c}\text { Nilai Rata- } \\
\text { rata }\end{array}$ \\
\hline 1. & $\begin{array}{l}\text { Pengantar Ilmu Pariwisata } \\
\text { dan Perhotelan }\end{array}$ & 83,83 \\
\hline 2. & Operational Kantor Depan & 77,16 \\
\hline 3. & Operational Tata Graha & 77,06 \\
\hline & Rata-rata prestasi & 79,35 \\
\hline
\end{tabular}

Sumber: LED Sapto

Melihat rata-rata prestasi yang diperoleh mahasiswa Angkatan 2018/2019 di atas menunjukkan bahwa prestasi yang diperoleh belum optimal. Kenyataan tersebut dapat disebabkan oleh beberapa faktor mengingat kemampuan antara mahasiswa yang satu dengan yang lain berbeda-beda. Prestasi belajar dipengaruhi oleh dua faktor yaitu faktor internal dan faktor eksternal. Faktor internal yaitu faktor yang bersumber dari dalam individu seperti faktor jasmaniah, 
psikologi dan faktor kelelahan. Sedangkan faktor eksternal adalah semua faktor yang bersumber dari luar seperti lingkungan keluarga, sekolah dan masyarakat ( Slameto, 2010:54).

Berdasarkan teori tersebut minat dan motivasi belajar diduga menentukan prestasi belajar mahasiswa di Politeknik Pariwisata Batam. Minat dapat diartikan kecenderungan untuk merasa tertarik atau terdorong untuk memperhatikan seseorang, sesuatu barang atau kegiatan dalam bidang- bidang tertentu. Selain minat, dalam proses pembelajaran masalah yang dihadapi oleh pendidik (guru/dosen) dan anak didik (siswa atau mahasiswa) adalah motivasi. Motivasi adalah keseluruhan daya penggerak di dalam diri siswa yang menimbulkan kegiatan belajar, yang menjamin kelangsungan kegiatan belajar dan yang memberikan arah kegiatan belajar sehingga tujuan yang dikehendaki oleh subyek belajar itu dapat tercapai (Sardiman,2010:75). Seseorang akan berhasil dalam belajar, kalau pada dirinya sendiri ada keinginan untuk belajar. Hal ini sesuai teori conditioning yang menyatakan bahwa dalam kegiatan belajar, motivasi merupakan faktor yang sangat penting (Sardiman,2010:37).

Seorang pendidik berusaha dan berharap supaya setiap peserta didik menggunakan bakat dan waktunya selama disekolah atau dikampus sehingga tujuan belajar terjadi secara maksimal. Siswa atau mahasiswa diharapkan menggunakan potensi mereka tumbuh secara cepat dengan perkembangan bakat- bakat mereka yang ada. Permasalahnya adalah bagaimana membujuk peserta didik untuk berusaha mengembangkan motivasi belajarnya.

Menurut Sardiman (2010:89) terdapat dua jenis motivasi, motivasi belajar bisa timbul dari dalam ( intrinsik ) maupun dari luar individu ( ekstrinsik). Motivasi yang muncul dari dalam individu akan lebih stabil dan mantap bila dibandingkan dengan motivasi belajar yang muncul karena pengaruh lingkungan (motivasi dari luar). Mahasiswa yang memiliki motivasi yang tinggi cenderung lebih aktif dalam usaha meningkatkan prestasinya.

Pernyataan tersebut sesuai dengan penelitian Asti Wahyuni ( 2007 ) di SMK Pelita Nusantara Semarang berdasarkan hasil analisis regresi menunjukkan bahwa motivasi belajar berpengaruh positif terhadap prestasi belajar yang dicapai. Tinggi rendahnya prestasi belajar yang telah dicapai dan dipengaruhi oleh motivasi belajar siswa sebesar 51,3\%. Jika dibandingkan dengan metode pembelajaran, motivasi belajar mempunyai pengaruh yang cukup tinggi terhadap prestasi belajar.

Motivasi belajar seseorang bisa dilihat dari kedisiplinannya dalam mengikuti kuliah, tingkat perhatiannya dalam mengikuti perkuliahan, frekuensi belajar saat dirumah atau di kost, dan lain-lain. Realitas yang dapat kita lihat, seorang mahasiswa yang sama-sama disiplin dalam masuk kuliah, dan memiliki perhatian yang sama pada saat mengikuti kuliah, tetapi memiliki prestasi yang berbeda-beda. Terkadang kondisi yang terjadi adalah mahasiswa yang jarang mengikuti kuliah justru memiliki prestasi yang tinggi dibandingkan dengan mahasiswa yang selalu masuk kuliah.

Kondisi ketidakwajaran inilah yang menimbulkan pertanyaan bagaimana peran minat dan motivasi belajar dalam pencapaian prestasi belajar. Minat yang rendah membuat motivasi mereka dalam prestasi menjadi berkurang dan motivasi yang rendah membuat mahasiswa tidak mempunyai motivasi untuk menyukai materi perkuliahan sehingga akan merasa kesulitan menerima dan menguasai mata kuliah pariwisata yang teorinya cenderung luas dan membutuhkan banyak pemikiran dan penalaran untuk memecahkan studi kasus. Hal ini menunjukkan bahwa tinggi rendahnya prestasi belajar dapat dipengaruhi oleh tinggi rendahnya minat dan motivasi belajar mahasiswa atau dapat pula dikatakan prestasi belajar mahasiswa yang belum optimal ini cenderung dipengaruhi oleh kurang optimalnya minat dan motivasi belajar mahasiswa.

\section{KAJIAN PUSTAKA}

Belajar merupakan proses penting bagi perubahan perilaku manusia dan mencakup segala sesuatu yang dipikirkan dan dikerjakan. Perubahan perilaku terjadi karena didahului oleh proses pengalaman. Melalui pengalaman yang satu ke pengalaman yang lain akan menyebabkan proses 
perubahan. Perubahan ini tidak hanya berkaitan dengan penambahan ilmu pengetahuan tetapi juga kecakapan, keterampilan, sikap, pengertian, harga diri, minat, watak dan penyesuaian diri.

Ada beberapa definisi tentang belajar, dalam Sardiman (2010:5) antara lain dapat diuraikan sebagai berikut:

a. $\quad$ Cronbach memberikan definisi : Learning is shown by a change inbehavior as a result of experience.

b. $\quad$ Harold Spears memberikan batasan : Learning is to observe, to read, to imitate, to try something themselves, to listen, to follow direction.

c. Geoch, mengatakan : Learning is a change in performance as a result of practice”. lain:

Menurut Darsono, (2000:5) disebutkan bahwa teori-teori belajar dalam pendidikan antara

1. Teori Belajar Behavioris

Diantara tokoh yang mencetuskan teori behavioris adalah Thorndike, Pavlov dan Skinner yang berasumsi bahwa manusia adalah makhluk pasif, tidak mempunyai potensi psikologis yang berhubungan dengan kegiatan belajar antara lain pikiran, persepsi, motivasi dan emosi. Melalui asumsi seperti ini, manusia dapat direkayasa sesuai dengan tujuan yang hendak dicapai dan yang terpenting dalam belajar adalah pemberian stimulus yang berakibat terjadinya tingkah laku yang dapat diobservasi dan diukur.

\section{Teori Belajar Sosial}

Teori ini dipelopori oleh Bandura yang menyatakan bahwa tingkah laku manusia tidak hanya didorong oleh kekuatan dari dalam dirinya melainkan oleh interaksi yang kontinu dan timbal balik antara pribadi dan lingkungan. Teori ini mengandung dua konsep utama yaitu :

1. Pemodelan

Proses belajar siswa dilakukan dengan peniruan terhadap model sehingga ia dapat melakukan respon yang benar sesuai dengan model.

2. Fase belajar

Mencapai tujuan belajar, akan dilalui beberapa fase yaitu:

a) Perhatian

Perhatian merupakan awal dari peniruan. Model tidak akan ditiru tanpa dilihat atau di observasi

b) Retensi

Belajar melibatkan dua kejadian yaitu :memperhatikan penampilan dan memperhatikan penyajian simbolik dari penampilan tersebut. Agar model mudah di ingat, model itu harus dibuat sedemikian rupa sehingga jelas tertangkap oleh orang yang meniru.

c) Reproduksi

Reproduksi adalah proses memunculkan kembali sesuatu yang sudah tersimpan dalam ingatan.

d) Motivasi

Motivasi diartikan sebagai keinginan melakukan sesuatu yang sama dengan model karena dengan demikian ia akan merasa memperoleh reinforcement.

3. Teori Belajar Kognitif

Ahli-ahli yang menganut aliran kognitif berpendapat bahwa belajar adalah peristiwa internal artinya belajar baru dapat terjadi bila ada kemampuan dalam diri orang yang belajar. Kemampuan tersebut ialah kemampuan mengenal yang di sebut dengan istilah kognitif.

4. Teori Belajar Gestalt

Peletak dasar aliran ini adalah Wax Wertheimer yang menyatakan bahwa belajar diperlukan kemampuan mengorganisir obyek yang dipersepsi sehingga menjadi suatu bentuk yang bermakna dan mudah dipahami. 


\section{Teori Belajar Humanis}

Teori ini menyatakan bahwa manusia dianggap sebagai individu yang unik dan bisa mewujudkan potensi-potensi yang ada pada dirinya. Tokoh dalam aliran ini antara lain Abraham H. Maslow yang menyatakan bahwa dalam diri manusia terdapat dorongan untuk tumbuh dan kekuatan yang menghalangi pertumbuhan. Maslow mencetuskan teorinya tentang motivasi yakni teori hirarki kebutuhan yang artinya bahwa kebutuhan manusia bersifat hirarkis dimana suatu kebutuhan mulai dipikirkan apabila kebutuhan di bawahnya mendahului sudah terpenuhi.

Menurut Winkel, belajar adalah aktivitas mental atau psikis yang berlangsung dalam interaksi aktif dengan lingkungan yang menghasilkan perubahan dalam pengetahuan, pengalaman, keterampilan, dan nilai sikap. Nasution ( 1995:34) juga berpendapat bahwa belajar diartikan sebagai perubahan kelakuan berkat pengalaman dan latihan. Perubahan itu hanya mengenai jumlah pengetahuan dengan bentuk kecakapan, minat, penyesuaian diri, kedewasaan sikap, pengertian, penghargaan, pendekatan mengenai segala aspek organisme/pribadi seseorang.

Atas beberapa teori tersebut, dapat ditarik kesimpulan bahwa belajar merupakan suatu usaha yang dilakukan secara sungguh-sungguh dan sistematis dengan mendayagunakan potensi yang dimiliki, baik fisik maupun mental yang berupa panca indera, otak, dan bagian tubuh lainnya.

Demikian pula aspek kejiwaan seperti intelegensi, bakat, minat, dan motivasi yang bertujuan untuk mengadakan perubahan tingkah laku, kebiasaan sikap, keterampilan, serta menambah dalam berbagai disiplin ilmu.

Menurut Syach (2003:136), minat merupakan kecenderungan dan kegairahan yang tinggi atau keinginan yang besar terhadap sesuatu. Seorang mahasiswa yang mempelajari suatu bahan kuliah dengan penuh minat akan memperoleh hasil yang lebih optimal dibandingkan mereka yang tidak atau kurang mempunyai minat dalam mempelajari bahan kuliah yang sama.

Suatu minat dapat diekspresikan melalui suatu pernyataan yang menunjukan bahwa mahasiswa lebih menyukai suatu hal dari pada yang lainnya dapat pula dimanifestasikan melalui partisifasi dalam bentuk aktifitas. Mahasiswa memiliki minat terhadap subjek tertentu cenderung untuk memberikan perhatian yang lebih besar terhadap subjek tersebut. Karena pemusatan perhatian yang intensif terhadap meteri pelajaran dapat memungkinkan mahasiswa untuk belajar lebih giat dan akhirnya mencapai prestasi yang diinginkan. Kesimpulannya minat belajar adalah suatu pemusatan perhatian atau rasa lebih suka terhadap pariwisata sehingga ingin menguasai materi tersebut.

Melakukan perbuatan mengajar secara relatif tidak semudah melakukan kebiasaan yang rutin dilakukan. Diperlukan adanya sesuatu yang mendorong kegiatan belajar agar semua tujuan yang diinginkan dapat tercapai. Hal tersebut adalah adanya motivasi. Menurut Whittaker yang dikutip Darsono (2000:61) motivasi adalah suatu istilah yang sifatnya luas yang digunakan dalam psikologi yang meliputi kondisi- kondisi atau keadaan internal yang mengaktifkan atau memberi kekuatan pada organisme dan mengarahkan tingkah laku organisme mencapai tujuan. Menambahkan menurut Winkel, motivasi adalah motif yang sudah menjadi aktif pada saat-saat melakukan percobaan, sedangkan motif sudah ada dalam diri seseorang jauh sebelum orang itu melakukan suatu perbuatan.

Berkaitan dengan proses belajar mahasiswa, motivasi belajar sangatlah diperlukan. Diyakini bahwa hasil belajar akan meningkat kalau mahasiswa mempunyai motivasi belajar yang kuat. Menurut Hamzah (2007:23), motivasi belajar timbul karena faktor intrinsik, berupa hasrat dan keinginan berhasil dan dorongan kebutuhan belajar, harapan akan cita-cita. Faktor ekstrinsiknya adalah adanya penghargaan, lingkungan belajar yang kondusif, dan kegiatan belajar yang menarik.

Motivasi dalam proses belajar dapat tumbuh maupun hilang atau berubah dikarenakan adanya faktor-faktor yang mempengaruhinya. Beberapa faktor-faktor yang mempengaruhi motivasi belajar yaitu: 
(1) Cita-cita atau Aspirasi

Cita-cita disebut juga aspirasi adalah suatu target yang ingin dicapai. Penentuan target ini tidak sama bagi semua mahasiswa. Cita-cita atau aspirasi adalah tujuan yang ditetapkan dalam suatu kegiatan yang mengandung makna bagi seseorang, Winkel (1989:96) dalam Darsono. Aspirasi ini bisa bersifat positif dan negatif, ada yang menunjukkan keinginan untuk mendapatkan keberhasilan tapi ada juga yang sebaliknya. Taraf keberhasilan biasanya ditentukan sendiri oleh mahasiswa dan berharap dapat mencapainya.

(2) Kemampuan Belajar

Taraf perkembangan berfikir mahasiswa menjadi ukuran, dalam kemampuan belajar ini. Jadi mahasiswa yang mempunyai kemampuan belajar tinggi biasanya lebih termotivasi dalam belajar.

(3) Kondisi Mahasiswa

Kondisi mahasiswa yang mempengaruhi motivasi belajar berhubungan dengan kondisi fisik dan kondisi psikologis. Biasanya kondisi fisik lebih cepat terlihat karena lebih jelas menunjukkan gejalanya daripada kondisi psikologis. Kondisi-kondisi tersebut dapat mengurangi bahkan menghilangkan motivasi belajar mahasiswa.

(4) Kondisi Lingkungan

Kondisi lingkungan yang dimaksud adalah lingkungan keluarga, lingkungan kampus dan lingkungan masyarakat. Ketiga lingkungan ini sangat berpengaruh terhadap motivasi belajar mahasiswa.

(5) Unsur-unsur Dinamis dalam Belajar

Unsur-unsur dinamis dalam belajar adalah unsur-unsur yang keberadaannya dalam proses belajar tidak stabil, kadang-kadang kuat, kadang-kadang lemah dan bahkan hilang sama sekali, khususnya kondisi-kondisi yang sifatnya kondisional.

(6) Upaya Dosen Membelajarkan Mahasiswa

Dosen mempersiapkan diri dalam membelajarkan siswa mulai dari penguasaan materi sampai dengan mengevaluasi hasil belajar mahasiswa. Upaya tersebut berorientasi pada kepentingan mahasiswa diharapkan dapat meningkatkan motivasi belajar.

Indikator motivasi belajar menurut Hamzah (2007:23) :

1. Adanya hasrat dan keinginan berhasil

2. Adanya dorongan dan kebutuhan dalam belajar

3. Adanya harapan dan cita-cita masa depan

4. Adanya penghargaan dalam belajar

5. Adanya kegiatan yang menarik dalam belajar

6. Adanya lingkungan belajar yang kondusif,sehingga memungkinkan seseorang mahasiswa dapat belajar dengan baik

Apabila seseorang telah memiliki ciri-ciri motivasi di atas maka orang tersebut selalu memiliki motivasi yang cukup kuat. Kegiatan belajar mengajar akan berhasil baik, kalau mahasiswa tekun mengerjakan tugas, ulet dalam memecahkan berbagai masalah dan hambatan secara mandiri.

\section{HASIL DAN PEMBAHASAN}

Hal yang di kaji penulis dalam penelitian ini adalah mengenai pengaruh minat dan motivasi belajar terhadap prestasi belajar mahasiswa di Politeknik Pariwisata Batam dengan kerangka berpikir yang merupakan model konseptual tentang bagaimana teori berhubungan dengan berbagai faktor yang telah di identifikasi masalah yang penting. Berikut ini kerangka berpikir penulis : 


\section{Gambar 1.1 Kerangka Berpikir}

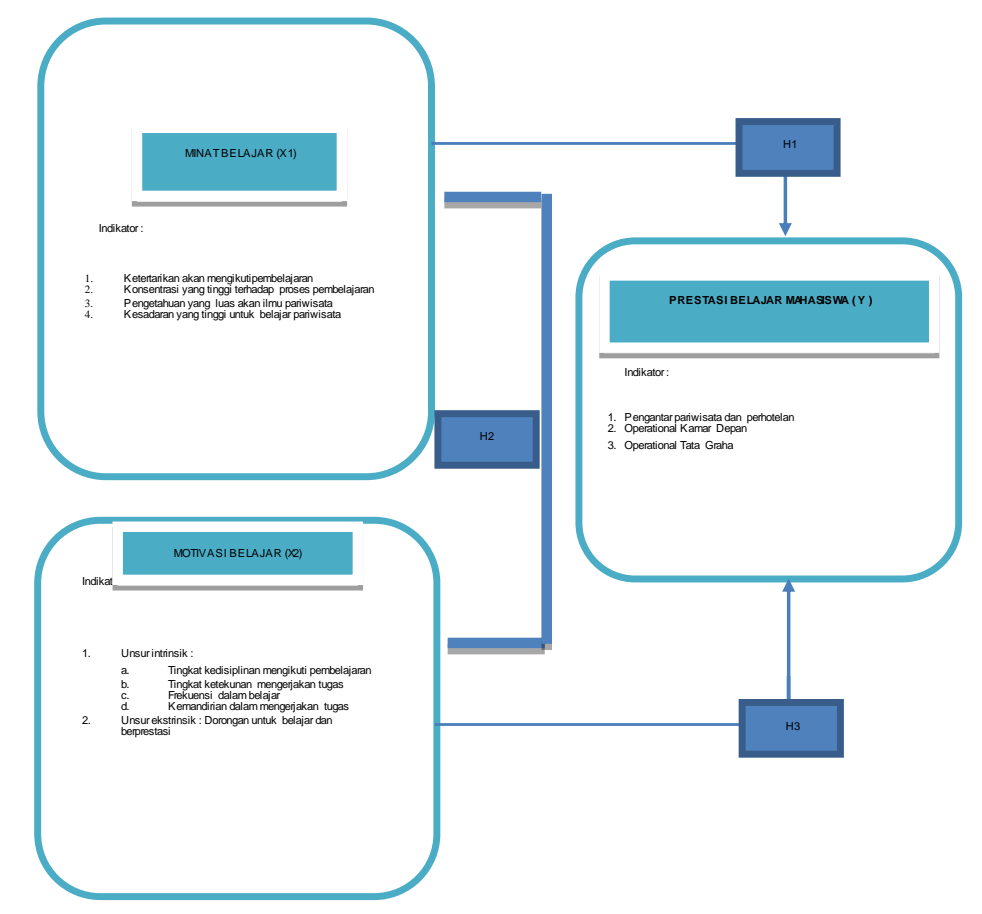

Penelitian ini di lakukan berdasarkan observasi langsung oleh peneliti langsung di lokasi objek penelitian. Sedangkan, untuk data sekunder, peneliti juga mendapatkan bantuan dari Manajemen Politeknik Pariwisata Batam yang berkutat di masalah akademik yaitu Administrasi dan Kemahasiswaan.

Wawancara, observasi, dan studi dokumentasi adalah berbagai macam cara dan metode yang digunakan oleh peneliti untuk mengumpulkan data. Dalam rangka pengumpulan data sekunder maka peneliti menggunakan wawancara. Sedangkan dalam rangka pengumpulan data primer, peneliti melakukan observasi langsung dan juga melakukan studi dokumentasi selama beberapa hari di lapangan. Dalam proses ini, peneliti juga melakukan wawancara tidak terstruktur terhadap mahasiswa manajemen divisi kamar Politeknik Pariwisata Batam. Pengolahan data dilakukan setelah data terkumpul. Dalam proses pengolahan data ini dilakukan proses pemilahan dan pengelompokan terhadap data yang diperoleh langsung di lapangan serta data sekunder. Hasil dari pengklasisfikasian tersebut kemudian dibuatkan ke dalam narasi data yang untuk kemudian ditarik menjadi kesimpulan. Kesimpulan ini diharapkan akan mewakili perspektif mahasiswa, dan juga manajemen Politeknik Pariwisata Batam yang menangani kegiatan harian mahasiswa.

\section{KESIMPULAN}

Berdasarkan penelitian ini dapat disimpulkan bahwa minat dan motivasi belajar tidak sepenuhnya mempengaruhi prestasi belajar namun perubahan besar kecilnya kedua variabel tersebut dapat mempengaruhi besar kecilnya prestasi belajar mahasiswa. Menyadari akan hal tersebut minat dan motivasi perlu ditingkatkan untuk mencapai prestasi belajar yang diinginkan. Salah satu upaya yang dilakukan yaitu dengan memberikan kesempatan kepada mahasiswa untuk berperan aktif dalam proses pembelajaran. Hal ini berdasarkan hasil deskripsi data jawaban angket bahwa untuk indikator kesadaran untuk belajar sebanyak $48 \%$ mahasiswa dalam kategori cukup tinggi. Kesadaran untuk belajar yang cukup tinggi inilah yang masih membuat prestasi belajar mahasiswa angkatan 2018/2019 belum optimal.

Minat belajar lebih diutamakan pada diri mahasiswa itu sendiri, minat timbul tanpa adany a paksaan. Mahasiswa diharapkan mampu menumbuhkan minat dengan berusaha meningkatkan pemahaman tentang akuntansi dan sebagai fasilitator pendidik diharapkan dapat memberikan 
bimbingan dan dorongan. Prestasi belajar juga dapat ditingkatkan dengan motivasi belajar. Salah satu upaya yang dilakukan untuk meningkatkan motivasi belajar mahasiswa adalah dengan meningkatkan penghargaan terhadap usaha.

Frekuensi belajar yang masih cukup tinggi juga perlu ditingkatkan dengan adanya pemberian tugas yang terorganisir, sehingga mahasiswa termotivasi untuk belajar. Motivasi belajar mahasiswa juga harus ditingkatkan dengan meningkatkan kemampuan dosen dalam memahami setiap kesulitan belajar mahasiswa. Hal ini terlihat pada deskripsi jawaban angket membuktikan bahwa kemandirian mahasiswa dalam menyelesaikan tugas masih kurang. Sebanyak 18\% mahasiswa masih membutuhkan bantuan dalam menyelesaikan tugas mereka, ini berarti mereka masih menemukan banyak kesulitan dalam belajar. Kemandirian mahasiswa dalam mengerjakan tugas sudah baik, tetapi untuk suatu kondisi tetentu mereka mengalami kesulitan untuk menyelesaikan tugas mereka, sehingga mereka harus meminta bantuan kepada teman mereka bahkan jika terpaksa mereka akan menyontek.

Keadaan seperti inilah yang karena keterbatasan pendidik (dosen) mengampu lebih banyak mahasiswa daripada seorang dosen, sehingga kemampuan untuk memahami anak didik menjadi terbatas pula. Peningkatan minat oleh mahasiswa dapat diupayakan melalui peningkatan pemahaman tentang akuntansi secara mendalam. Atas kondisi tersebut disarankan pula peran serta pendidik dalam membimbing mahasiswa dapat ditingkatkan. Pemberian reward dianggap perlu agar mahasiswa termotivasi untuk belajar dan berprestasi.

\section{Ucapan terima kasih}

Dengan terselesaikannya penelitian ini, penulis mengucapkan terimakasih sedalam-dalamnya kepada:

1. Tuhan Yang Maha Esa. atas limpahan karunia dan hidayahnya sehingga penulis dapat menyelesaikan penelitian ini.

2. Ayah dan Ibu penulis tercinta yang senantiasa mendoakan penulis.

3. Yayasan Vitka yang telah memberikan kesempatan kepada penulis untuk melaksanakan penelitian ini.

4. Pihak lain yang tidak dapat penulis sebutkan satu per satu, yang telah membantu penulis dalam pelaksanaan penelitian ini.

\section{DAFTAR PUSTAKA}

Anni, Chatarina Tri, dkk. 2006. Psikologi Belajar. Semarang: UPT MKK Unnes. Andriani, Gumelar . 2005. Faktor-Faktor Yang Mempengaruhi Prestasi Belajar

Akuntansi Pada Siswa Kelas I Smk Tu Semarang 2003/2004.

Arikunto, Suharsimi. 2002. Prosedur Penelitian Suatu Pendekatan Praktek. Jakarta: Rineka Cipta.

Dalyono, M. 1997. Psikologi Pendidikan. Jakarta: Rineka Cipta.

Darsono, Max. 2000. Belajar dan Pembelajaran. Semarang: CV. IKIP Semarang Press.

Djamarah, Syaiful Bahri. 2010. Psikologi Belajar. Jakarta: Rineka Cipta. Hamalik, Oemar. 2005. Proses Belajar Mengajar. Jakarta: Bumi Aksara Sardiman, AM. 2010. Interaksi dan Motivasi Belajar Mengajar. Jakarta: PT. Raja Grafindo Persada. 
Setiyoningsih, Retno. 2007. Faktor-Faktor Yang Mempengaruhi Prestasi Belajar Pada Mahasiswa Program Studi Pendidikan Akuntansi Fakultas Ekonomi Angkatan 2003 di Universitas Negeri Semarang.

Slameto. 2010. Belajar dan Faktor-faktor yang Mempengaruhinya. Jakarta: Rineka Cipta.

Sudjana. 1996. Metoda Statistika. Bandung: Tarsito

Syah, M. 2003. Psikologi Pendidikan Dengan Pendekatan Baru (Edisi Revisi). Bandung:Remaja Rosdakarya

Tu'u, Tulus. 2004. Peran Disiplin Pada Perilaku dan Prestasi Siswa. Jakarta: Grasindo.

UNNES. 2006. Buku Informasi Unnes 2006/2007. Semarang: Unnes PRESS

Wahyuni, Asti. 2007. Pengaruh Motivasi Belajar dan Metode Pembelajaran Terhadap Prestasi Belajar Akuntansi Siswa Kelas I Jurusan Akuntansi SMK Pelita Nusantara 1Semarang.

Winarni .2004 . Hubungan antara minat baca terpola dengan prestasi belajar siswa kelas VI SD Negeri di Desa Tampingan Kecamatan Boja Kabupaten Kendal tahun pelajaran 2002/2003. 